\title{
ROOT MORPHOLOGY AND CHEMISTRY IN MANCHURIAN ASH (FRAXINUS MANDSHURICA) AND LARCH (LARIX GMELINII RUPR.) ARE DEPENDENT ON SPECIES, ROOT ORDER AND COMPETITION
}

\author{
Salahuddin $^{* 1,2}$, M. Razaq ${ }^{3}$, A. Khan ${ }^{1}$ and M. S. Haider ${ }^{3}$ and Y. Lixue ${ }^{1}$, \\ ${ }^{1}$ School of Forestry, Northeast Forestry University, Harbin-China; ${ }^{2}$ Agricultural Research Institute, Mingora Pakistan. \\ ${ }^{3}$ University College of Agriculture, Department of Forestry, University of Sargodha, Pakistan.
} Corresponding Author's E-mail: ylx 0813@163.com

https://doi.org/10.36899/JAPS.2020.1.0014

Published online January 02,2020

\begin{abstract}
Interspecific variation in fine-root morphology and function is well documented. However, very less information is available regarding variation among monoculture and mixed-species plantations in temperate species. Thus, the present study used such plantations to investigate how belowground inter- and intraspecific competition influence major fineroot traits of larch (Larix gmelinii) and Manchurian ash (Fraxinus mandshurica). Overall root morphology, anatomy, and chemistry differed between species and root order (1-5). Specific root length, nitrogen concentration, and cortex: stele ratio was significantly higher in Manchurian ash, whereas root tissue density, stele diameter, and $\mathrm{C} / \mathrm{N}$ ratio were significantly higher in larch. Additionally, when comparing the two species in a mixed plantation, root $\mathrm{C}$ concentration differed significantly between larch and Manchurian ash, but only for the second root order. However, root traits were largely similar across species within a given root order. In conclusion, critical root traits did not exhibit major intra- and interspecific differences, despite the ostensible presence of competition among tested plantations. Therefore, competition-induced root modification may not be a universal phenomenon in temperate trees.
\end{abstract}

Key words: Root morphology, Root order, N content, Root tissue density, Specific root length.

\section{INTRODUCTION}

Monoculture and mixed-species forests are increasingly understood to have differential effects on ecosystem functioning that manifest as variation in productivity and resource acquisition. Mixed plantations are typically superior to monoculture plantation (Chen et al., 2003; Erickson and Marshall, 2009; Lei and Peng, 2009) in terms of yield, likely the net result of beneficial above- and below ground interactions (Falik and Novoplansky, 2003; Jose and Zamora, 2006; Schenk and Mahall, 1999). In China, larch (Larix gmelinii) is an economically important timber species that also appears to positively influence Manchurian ash (Fraxinus mandshurica Rupr.) productivity in mixed plantations. For instance, larch root/bark extracts and root exudates increased chlorophyll, soluble sugar, and overall biomass in Manchurian ash and Manchurian walnut (Juglans mandshurica). Furthermore, larch root exudates increased soil microbial community populations and enzymatic activity in a larch-Manchurian walnut mixed plantation (Li et al., 2016; Schenk, 2006; Yang, 2006; Yang and Kong, 2010). Bulk-soil phenolic acids from larch increased soil microbial biomass and growth in Manchurian ash (Zhang et al., 2016). These findings suggest that plants may shift chemical strategies when cultivated with a different species, versus in a monoculture environment.
Previous studies investigations have focused on the above-ground responses, but little is known about the effects of tree species in mixture on structure and function of the below-ground organs of trees. In forests, belowground resource competition occurs through fine roots, a process that is as intense or more intense than shoot competition (Casper and Jackson, 1997; Coomes and Grubb, 2000; Wilson, 1988) and can either be exploitative (Schenk, 2006). Root competition has the potential to decrease the productivity of the competing plants and it may trigger adaptive morphological and physiological responses of the roots and root systems. Generally, Root competition may be more or less symmetric but can also be asymmetric (Rewald and Leuschner, 2009; Schenk, 2006) which may lead to the eventual competitive exclusion of inferior competitors that altered resource availability in the soil affect the neighbor roots. Previous greenhouse experiments showed that Manchurian ash out competes larch in mixed plantations (Zhang and Wang, 2001). This outcome is supported by slower root growth in larch compared with vigorous growth in Manchurian ash Cui (1997). Nevertheless, more research is necessary to fully understand their mutual interspecific root responses in a mixed plantation system.

Fine roots $(\leq 1-2 \mathrm{~mm})$ are particularly worth attention, as fine roots exert major influence on soil biological activity and the carbon cycle in forests 
worldwide (Eissenstat et al., 2000; Norby et al., 2004). Fine root consists of individual distal roots order perform various morphological and physiological functions (Pregitzer et al., 2002). Fine roots can be divided into absorptive fine roots (1-3 order) and transport fine roots (higher orders) (Mccormack et al., 2015). Absorptive fine roots with thin diameter and with primary development are utilized for acquisition and uptake of soil resources, whereas the higher order roots with secondary growth for transportation and storage (Gu et al., 2014; Xia and Pregitzer, 2010). The distinct traits of these roots in a given species can strongly influence a plant community's productivity and biogeochemical cycles (Fornara and Hobbie, 2009; Orwin et al., 2010).

Fine roots may adapt to increasing specific root surface area (SRA) and specific root length (SRL) which would reduce the cost of exploring additional soil volume by the formation of new roots in the below ground competition. Similarly, various studies reported morphological root adaptation in response to the presence of competitors in forest ecosystems (Bolte and Villanueva, 2006; Fujii and Kasuya, 2008). Spatial and temporal variability in belowground resource availability, plasticity in fine root traits may be an essential element of plant strategies to cope with belowground competition (Berg and Mcclaugherty, 2008; Hodge and Fitter, 2010).

Root morphological and functional traits variability within the same tree species is to investigate root morphological adaptation in response to interspecific and intraspecific belowground competition with assumed asymmetric outcome. Previous studies demonstrated that different root segments fulfill different functions and that root order may have a large effect on root functionality even within the fine roots (Fitter, 1991; Guo et al., 2008; Pregitzer et al., 2002). Most previous studies, however, focused on solely on root biomass or production through field observations (Lei and Bauhus, 2012; Rewald and Leuschner, 2009) or experiments (Hertel and Leuschner, 2006; Rewald and Rachmilevitch, 2010) in natural and artificial mixed forests. Therefore, here we used monoculture and mixed forests of Manchurian ash and larch to examine how root-to-root interactions affect on major morphological, anatomical, and chemical traits across five fine-root orders.

\section{MATERIALS AND METHODS}

Site description: This experiment was conducted at the Maoershan experimental station $\left(4^{\circ} 16^{\prime} \mathrm{N}, 128^{\circ} 34^{\prime} \mathrm{E}\right)$, located in the temperate forest region of the Heilongjiang Province, NE China. The climate is a continental monsoon climate featuring a strong monsoon in the spring, a warm and humid summer, and a dry and cold winter. The average annual air temperature is $2.8^{\circ} \mathrm{C}$; average temperatures in January and July are $-19.6^{\circ} \mathrm{C}$ and $20.9^{\circ} \mathrm{C}$, respectively. The frost-free period is 120 to 140 days-long. The annual averages of rel. humidity, precipitation, and potential evapotranspiration are $70 \%$, $724 \mathrm{~mm} \mathrm{a}^{-1}$, and $1094 \mathrm{~mm} \mathrm{a}^{-1}$, respectively. The parent material is granite bedrock and soils are Boric Luvisols (Gong and Zhang, 2003) the bulk soil density $(0-10 \mathrm{~cm}$ depth) is $0.83 \mathrm{~g} \mathrm{~cm}^{-3}$ (Razaq et al., 2017) further soil characteristics are listed in Table 1.

Larch (Larix gmelinii Rupr.) and Manchurian ash (Fraxinous mandschurica) are dominant species in natural forests, and key species used for plantations in Northeast China. The two species contrast in taxonomy (gymnosperm $v s$. angiosperm), and due to their economic importance, large monocultures and mixed plantations of the two species were established in the region in 1987; 2year-old seedlings were planted in a $1.5 \mathrm{~m} \times 1.5 \mathrm{~m}$ grid (between rows $\times$ within rows) in all three stands. Line mixing (i.e. three rows of Manchurian ash followed by five rows of larch) was used in the mixed-species plantation.

Root morphology, chemistry, and anatomy measurement: During September 2017, root samples were obtained from selected larch and Manchurian ash in monoculture and mixed plantations. After excess soil was removed, samples were stored in plastic bags, kept in an icebox, and then transported to the laboratory. Roots were then washed more thoroughly with de-ionized water to remove remaining soil particles. Cleaned roots were then separated by species and branch order, then scanned with an Expression 10000XL 1.0 scanner (Epson, Suwa, Japan). The resultant images were analyzed in WinRHIZO Pro2004b (Reagent Instruments Inc., Canada) to determine average root diameter and length. After scanning, roots were oven-dried at $65^{\circ} \mathrm{C}$ to calculate dry mass. Root tissue density (RTD, $\mathrm{m}^{2} \mathrm{~g}^{-1}$ ) and specific root length (SRL, $\mathrm{m} \mathrm{g}^{-1}$ ), were then determined using measured root length and dry mass. Subsequently, samples were weighed after a second oven-drying at $75^{\circ} \mathrm{C}$ for $72 \mathrm{~h}$, then ground and homogenized for further chemical analysis. Tissue $\mathrm{N}$ and $\mathrm{C}$ content were determined using a Macro Elemental Analyzer (vario MACRO, Hanau, Germany).

Five randomly selected root branches per species and forest type (see "Site description" for sampling scheme) were gently washed in de-ionized water, immediately fixed in formalin-aceto-alcohol

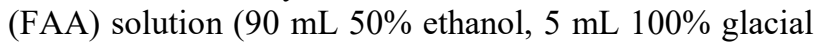
acetic acid, $5 \mathrm{~mL} 37 \%$ methanol), and stored at $4^{\circ} \mathrm{C}$. First- and second-order roots (30 each) were stained with safranin-fast green, dehydrated in an alcohol series (70, $85,95,100 \% \mathrm{EtOH})$, and embedded in paraffin. Crosssections $(8 \mu \mathrm{m})$ were prepared with a microtome and photographed under a compound microscope (BX-51; Olympus Corporation, Tokyo, Japan). Cortex thickness $(\mu \mathrm{m})$ and stele diameter $(\mu \mathrm{m})$ were measured Guo et al. (2008) to calculate the cortex: stele ratio. 
Statistical analysis: All statistical analyses were performed in SPSS version (IBM SPSS 21.0). Two ANOVAs were used to test for significant differences across species as random factor and treatment as fixed factor (monoculture versus mixed); means were separated with post-hoc Tukey's HSD tests. A principal components analysis (PCA) was employed in CANOCO 4.5 for Windows (http://www.canoco5.com/) to determine overall explanatory variables from chemical and morphological traits. Additionally, general linear models (GLM) were used to analyze critical root traits, with species, forest type, and root order included as factors.

\section{RESULTS}

Interspecific and root-order difference in monoculture and mixed plantations: $\mathrm{We}$ found significant differences in between species and root order in morphology, chemistry, and anatomy (Table 1). Manchurian ash exhibited significantly greater specific root length, $\mathrm{N}$ concentration, and cortex: stele ratio than larch, while larch exhibited significantly greater diameter, $\mathrm{RTD}$ and $\mathrm{C} / \mathrm{N}$ ratio (Fig 1).
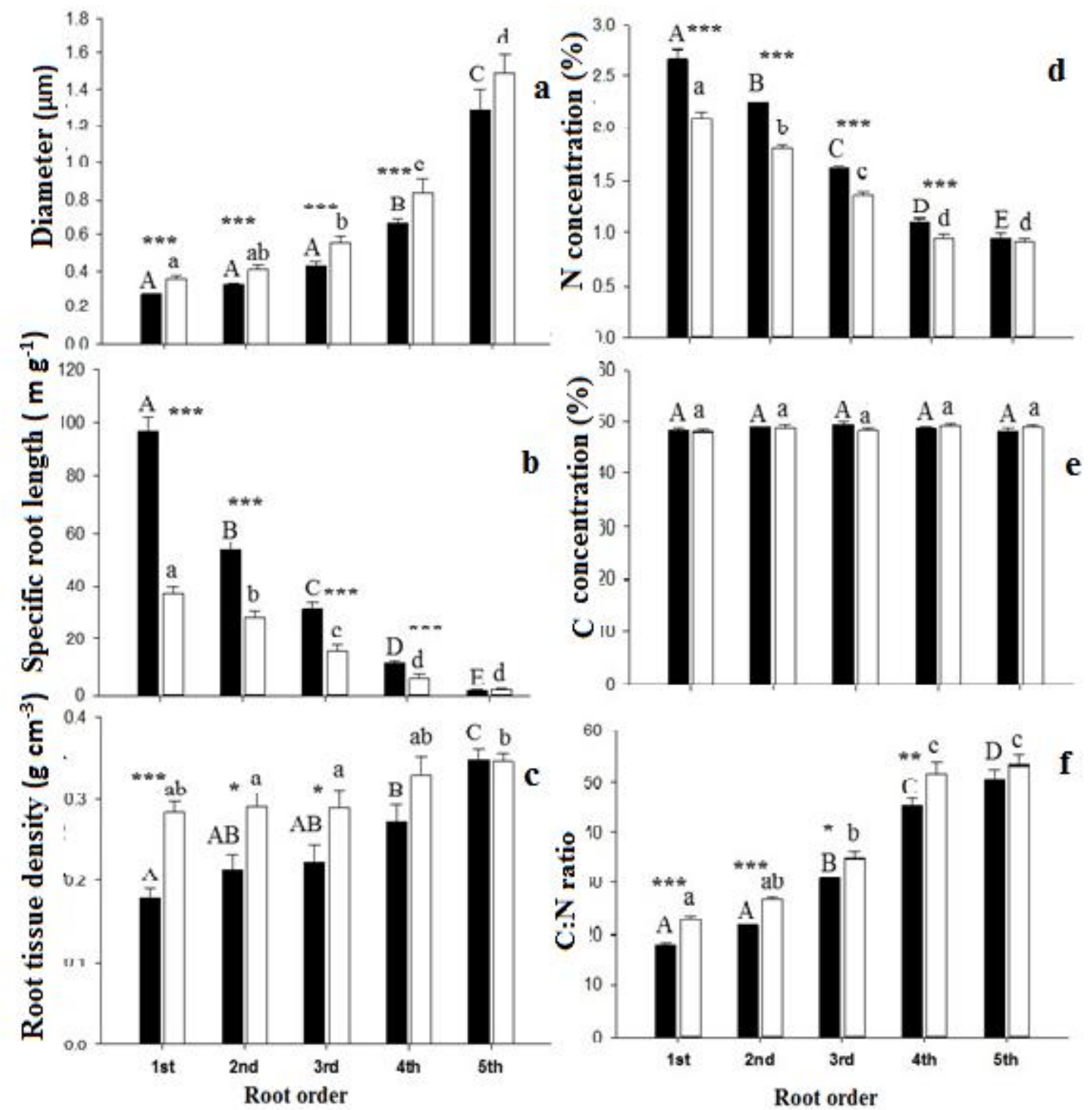

Figure 1. Root morpholgy (a-c) and chemistry (d-f) of root orders 1-5 of Manchurian ash (black) and larch (white) in monocultures. Significant differences in a given root order class between species are marked with an asterisks ( ${ }^{*} \mathrm{P} \leq 0.05 ;{ }^{* * *} \mathrm{P} \leq \mathbf{0 . 0 0 1}$, Tukey HSD; $\mathbf{n}=6 \mathbf{6 - 8}$; mean \pm SE). 
In both species, SRL, $\mathrm{N}$ concentration, and cortex:stele ratio decreased with increasing root order. First-order roots of Manchurian ash and larch, respectively, contributed $50 \%$ and $43 \%$ of total SRL across the five orders. Average root diameter and $\mathrm{C} / \mathrm{N}$ ratio also increased with increasing root order in both species. In Manchurian ash, RTD exhibited a stepwise increase among higher root orders (4-5), whereas in larch, RTD was more equally distributed across all orders.

Cortical thickness and $\mathrm{C}$ concentration did not show root-order differences in either species (Fig 1e; 2a). Finally, while stele diameter did not differ between firstand second-order Manchurian ash roots, the variable increased with increasing root order in larch (Fig. 2b).

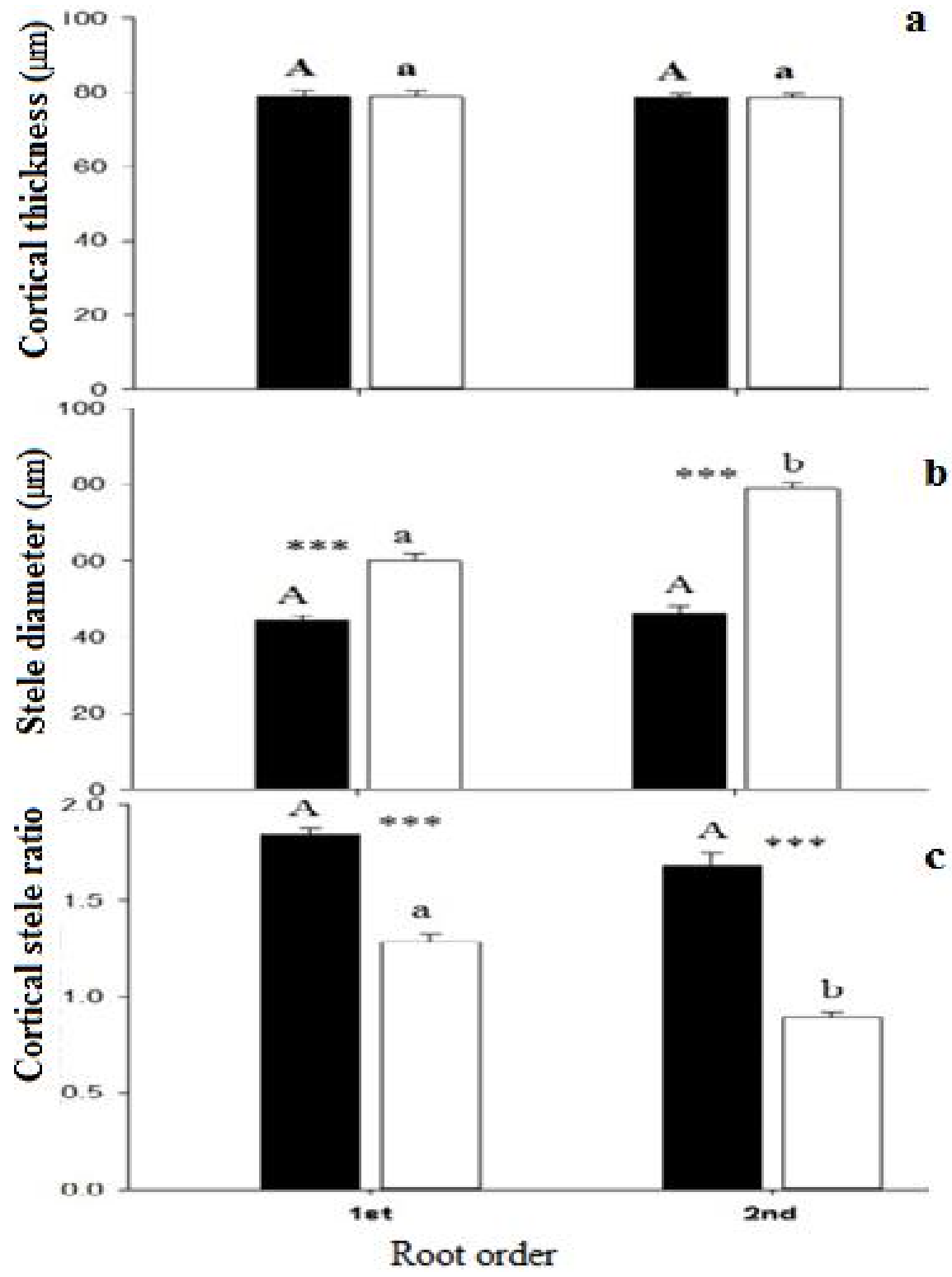

Figure 2. Root anatomy (a-c) of root orders 1-2 of Manchurian ash (black) and larch (white) in monocultures. Different upper case letters indicate significant differences between root orders of Manchurian walnut, lower case letters for larch $(P \leq \mathbf{0 . 0 5}$, Tukey HSD). Significant differences in a given root order class between species are marked with an asterisks ( ${ }^{*} \mathrm{P} \leq 0.05 ;{ }^{* * *} \mathrm{P} \leq \mathbf{0 . 0 0 1}$, Tukey HSD; $\mathrm{n}=\mathbf{2 0}$; mean $\left.\pm \mathrm{SE}\right)$.

Comparisons the root order across the monoculture and mixed plantations roots, we did not found many differences in root morphology, chemistry, or anatomy (Fig. 3). 

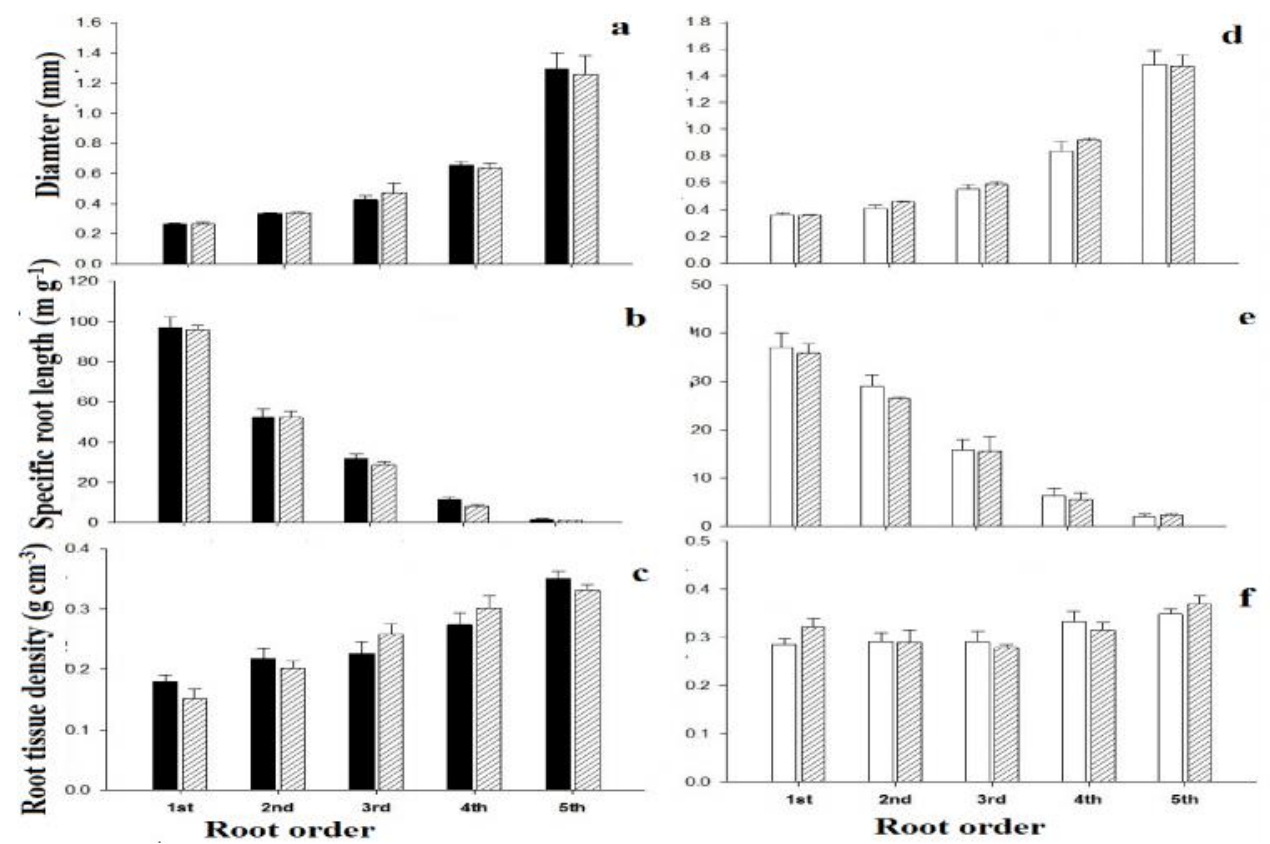

Figure 3. Root morpholgy of Manchurian walnut (a-c) and larch (d-f) root orders 1-5 in monocultures (walnut: black; larch: white) and mixed plantations (hatched). Please note differences in Y-axis scaling between species. Significant differences in a given root order classes per species between monoculture and mixed plantation are marked with an asterisks ( $\mathrm{P} \leq \mathbf{0 . 0 5} ;{ }^{* * *} \mathrm{P} \leq \mathbf{0 . 0 1} ;{ }^{* * * *} \mathbf{P} \leq \mathbf{0 . 0 0 1}$; Tukey HSD; $\left.\mathbf{n}=6-8 ; \mathrm{mean} \pm \mathrm{SE}\right)$ The only variable that differed was $\mathrm{C}$ concentration, which was significantly higher among second-order roots of mono Manchurian ash and larch mixed plantation roots (Fig. 4b; e).
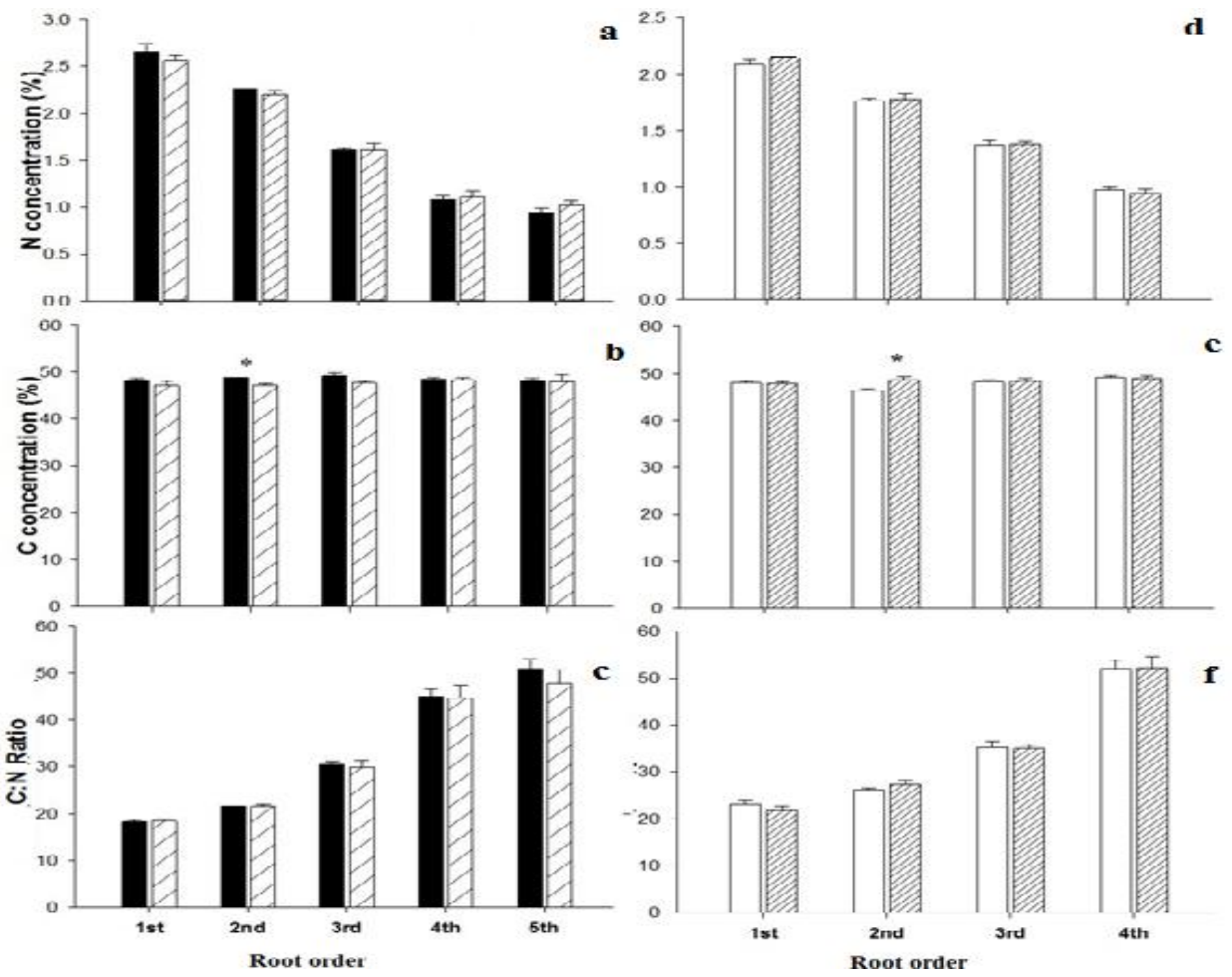

Figure 4. Root chemistry of Manchurian walnut (a-b) and larch (c-d) root orders 1-5 in monocultures (walnut: black; larch: white) and mixed plantations (hatched). Please note differences in Y-axis scaling between species. Significant differences in a given root order classes per species between monoculture and mixed plantation are marked with an asterisks $\left({ }^{*} \mathrm{P} \leq 0.05 ;{ }^{* *} \mathrm{P} \leq 0.01 ;{ }^{* * *} \mathrm{P} \leq 0.001\right.$; Tukey HSD; $\mathrm{n}=4-6$; mean $\pm \mathrm{SE}$ ) 


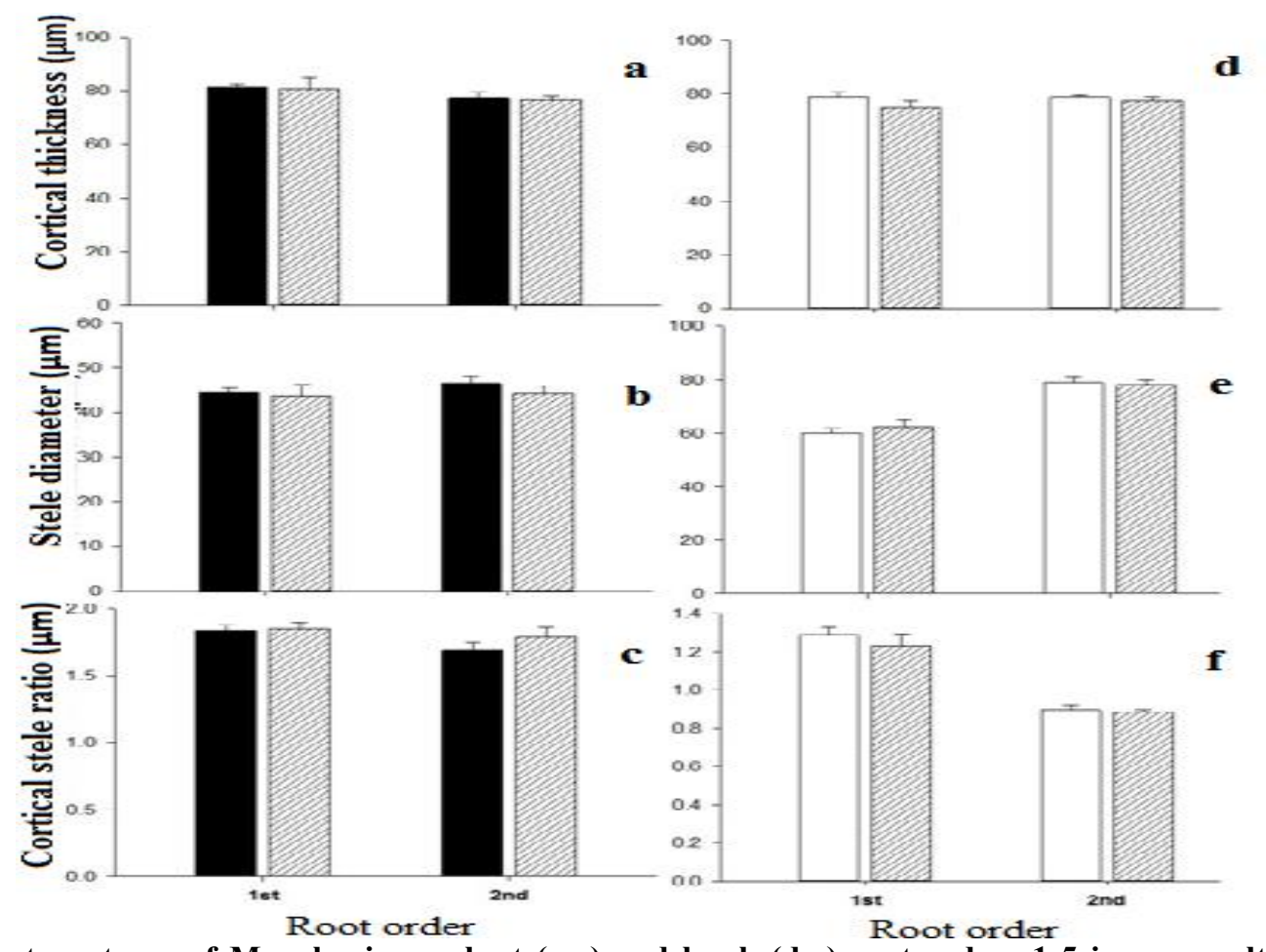

Figure 5. Root anatomy of Manchurian walnut (a-c) and larch (d-e) root orders 1-5 in monocultures (walnut: black; larch: white) and mixed plantations (hatched). Please note differences in Y-axis scaling between species. Significant differences in a given root order classes per species between monoculture and mixed plantation are marked with an asterisks $\left({ }^{*} \mathrm{P} \leq 0.05 ;{ }^{* * *} \mathrm{P} \leq 0.01 ;{ }^{* * *} \mathrm{P} \leq 0.001 ;\right.$ Tukey HSD; $\left.\mathbf{n}=\mathbf{2 0} ; \mathrm{mean} \pm \mathrm{SE}\right)$

Table 1 Results of a multiple General Linear Model (GLM) on the influence of tree species identity (Species), competition treatment: (mono or mix) and root order (1-5) and their interactions. Specific root length (SRL), Root tissue density (RTD) and root diameter, $N$ and $C$ concentration and $C / N$ ratio $(C: N)$.

\begin{tabular}{|c|c|c|c|c|c|c|c|}
\hline Source of variation & Df & $\mathbf{F}$ & $\mathbf{P}$ & $\mathbf{F}$ & $\mathbf{P}$ & $\mathbf{F}$ & $\mathbf{P}$ \\
\hline & & \multicolumn{2}{|c|}{ SRL } & \multicolumn{2}{|c|}{ Diameter } & \multicolumn{2}{|c|}{ RTD } \\
\hline Model & 19 & 193.369 & $\leq 0.001$ & 34.349 & $\leq 0.001$ & 11.231 & $\leq 0.001$ \\
\hline Species & 1 & 213.562 & $\leq 0.001$ & 19.836 & $\leq 0.001$ & 27.104 & $\leq 0.001$ \\
\hline Order & 4 & 441.342 & $\leq 0.001$ & 75.882 & $\leq 0.001$ & 24.019 & $\leq 0.001$ \\
\hline Treatment & 1 & 1.642 & 0.380 & 0.540 & 0.963 & 0.239 & 0.627 \\
\hline Species* Order & 4 & 52.774 & $\leq 0.001$ & 4.25 & $\leq 0.004$ & 4.312 & $\leq 0.007$ \\
\hline Treatment $*$ Order & 4 & 0.078 & 0.988 & 1.462 & 0.238 & 1.090 & 0.379 \\
\hline Treatment*Species & 1 & 1.893 & 0.174 & 0.436 & 0.511 & 0.346 & 0.558 \\
\hline \multirow[t]{2}{*}{ Order } & 4 & 0.247 & 0.910 & 1.403 & 0.244 & 0.534 & 0.711 \\
\hline & & \multicolumn{2}{|c|}{$\mathrm{N}$} & \multicolumn{2}{|c|}{$\mathrm{C}$} & \multicolumn{2}{|c|}{$\mathrm{C}: \mathrm{N}$} \\
\hline Model & 19 & 89.316 & $\leq 0.001$ & 101.144 & 0.033 & 2.9343 & $\leq 0.001$ \\
\hline Species & 1 & 84.111 & $\leq 0.001$ & 3.231 & 0.082 & 48.548 & $\leq 0.001$ \\
\hline Order & 4 & 200.535 & $\leq 0.001$ & 2.16 & 0.097 & 5.330 & $\leq 0.002$ \\
\hline Treatment & 1 & 0.272 & 0.606 & 1.383 & 0.049 & 0.005 & 0.946 \\
\hline Species* Order & 4 & 12.652 & $\leq 0.001$ & 8.371 & 0.679 & 2.051 & $\leq 0.02$ \\
\hline Treatment $*$ Order & 4 & 0.358 & 0.837 & 0.728 & 0.580 & 1.291 & 0.296 \\
\hline Treatment*Species & 1 & 0.082 & 0.776 & 4.02 & 0.049 & 0.108 & 0.743 \\
\hline $\begin{array}{l}\text { Treatment*Species* } \\
\text { Order }\end{array}$ & 4 & 0.615 & 0.654 & 0.473 & 0.756 & 0.391 & 0.815 \\
\hline
\end{tabular}

Shown are degrees of freedom (df) and the $\mathrm{F}$ and $\mathrm{P}$ value of the respective variables and the model itself. Variables with significant influence are printed in bold $(\mathrm{P} \leq 0.05)$ 
Table 2. Results of a Principal Components Analysis (PCA) on the morphological and chemical parameters as affected by root order, species and competition treatment. Given are the loadings of the selected variables along four explanatory axes. Numbers in brackets indicate the values of the axes \# 1 to 4 . Numbers in bold mark the variables with closest correlation to the respective axes.

\begin{tabular}{ccccc}
\hline Variables & Axis 1 & Axis 2 & Axis 3 & Axis 4 \\
\hline Species & 0.299 & -0.800 & 0.441 & -0.183 \\
Order & 0.983 & -0.001 & -0.097 & -0.088 \\
Treatment & 0.253 & -0.015 & -0.918 & 0.262 \\
SRL & 0.925 & 0.015 & 0.129 & 0.294 \\
Diameter & 0.902 & -0.091 & -0.096 & 0.162 \\
RTD & -0.943 & 0.024 & 0.156 & 0.228 \\
N & 0.949 & 0.046 & 0.028 & 0.214 \\
C & 0.487 & 0.076 & 0.853 & -0.162 \\
C:N & -0.002 & 0.996 & -0.077 & 0.011 \\
\hline
\end{tabular}

The results of PCA revealed that root order had the greatest explanatory power for all determined root traits. Additionally, species loaded strongly on axis 2, which also included $\mathrm{C} / \mathrm{N}$ ratio. Lastly, axis 3 contained $\mathrm{C}$ content and forest type, the latter loading more strongly than the former (Table 1). The results of GLM indicated that root order and species were the strongest predictors of RTD, root diameter, SRL, root $\mathrm{N}$, and $\mathrm{C} / \mathrm{N}$ ratio, but neither factor had an effect on root $\mathrm{C}$ concentration (Table 2).

\section{DISCUSSION}

The architectural traits of fine roots are the result of combining heterogeneous roots that differ in anatomical, morphological, chemical, and physiological characteristics (Eissenstat and Yanai, 1997; Lynch, 1995; Pregitzer et al., 2002). In this study, we demonstrated that Manchurian ash and larch differed in overall fine-root morphology, anatomy, and chemistry. Interspecific morphological variation in root length, diameter, SRL, and RTD lead to differences in root function across species (Coomes and Grubb, 2000; Eissenstat and Yanai, 1997; Pregitzer, 2002). Here, for example, we found that larch had thicker roots than Manchurian ash, thicker roots have increased longevity and slower turnover rates than thinner roots (Gill and Jackson, 2000; Wells and Eissenstat, 2002) resulting in thick-root species being more conservative (Luke et al., 2012; Reich, 2014) the observed morphological difference likely explains the superior competitive ability of Manchurian ash.

Both species, however, exhibited similar rootorder-related variation in diameter (Fig. 1a), associated with the distinct functions of lower- (absorptive) versus higher-order (transport) fine roots. Branch root orders have profound effect on the physiological and functional trait. For instance, first three lower order have higher functional and absorptive capacity, while higher order is believed to be use for transportation purpose (Gambetta et al., 2013; Mccormack et al., 2015). Interestingly, we observed between-species differences in root diameter, with the Manchurian ash having thinner fine roots and a greater cortex:stele ratio than larch. These findings suggest that Manchurian ash has more absorptive roots, while water transport capacity is likely to be higher in larch. Our results are in line with many previous studies demonstrating that fine roots with smaller diameters have heightened absorption capacity (Kong et al., 2014; Kong et al., 2016; Rewald et al., 2012) but short life spans compared with thicker roots (Luke et al., 2012).

Fine roots are quick responding plant organ that is influenced by a variety of dynamic factor including internal species heredity character and external environmental conditions e.g., nutrient availability, soil properties and competition between plants (Majdi et al., 2005). Root morphological indexes are believed to be important indicators of resources acquisition capability Leuschner et al. (2004) and construction cost (Eissenstat and Yanai, 1997; Ostonen et al., 2006) and root adaptation relation with varied plant competition conditions. Similarly, Root morphology traits and root distribution are assumed to be significant factors in determining the degree of interspecific belowground competition in mixed plantations system (George et al., 1996; Hauggaard et al., 2001). For Instance, Specific root length and root tissue density are critical important root traits for nutrients acquisition from the soil (Eissenstat $e t$ al., 2015). Besides having smaller diameters, Manchurian-ash fine roots also exhibited higher SRL and lower RTD than larch. Together, these three traits are characteristic of acquisitive, fast-growing species like Manchurian ash, in contrast to conservative, slowgrowing conifers such as larch (Luke et al., 2012; Reich, 2014). Acquisitive species appear capable of elevating their root respiration and $\mathrm{N}$ uptake through altering fineroot characteristics to improve nutrient and moisture acquisition capacity in a competitive environment (Reich et al., 1998). Surprisingly, we did not observe significant alterations in Manchurian ash root morphology in mixed forests, where it was in direct competition with larch. In contrast, when in a mixed forest with beech, Norway 
spruce (Picea abies) increased SRL of its fine roots (Bolte and Villanueva, 2006; Salahuddin et al., 2018). Similar alterations in root morphology have also been observed in grassland plants competing with their neighbors (Curt et al., 2005; Hees, 1997; Hubersannwald et al., 1997). Such opposing results may be linked to whether fast-growing or slow-growing species are more adapted to a given environment. The former group possesses low-density tissues that are indicative of a strategy to heighten resource-acquisition capacity through expanding stems, roots, or leaves with minimal investment in dry matter (Garnier et al., 2001; Poorter et al., 1991; Wahl and Ryser, 2000). However, the trade-off to fast growth is a greater sensitivity to infestation and disease compared with the high-density tissues typical of slow-growing species (Craine et al., 2001; Eissenstat and David, 1991; Tjoelker et al., 2005).

Fine root chemical traits characteristics are important for various root function and physiology (Wang et al., 2018). Nitrogen concentrations were significantly higher in Manchurian-ash roots than in larch roots (Fig. 1). This observation corroborates previous studies demonstrating that root order is inversely related to $\mathrm{N}$ concentration and directly related to $\mathrm{C} / \mathrm{N}$ ratio. The latter variable is an indicator of root life-span (Withington et al., 2006), with a higher $\mathrm{C} / \mathrm{N}$ ratio associated with slower turnover (Luke et al., 2012; Pregitzer et al., 2002). Although we identified an interspecific difference in $\mathrm{N}$ concentrations, overall $\mathrm{C}$ concentrations did not differ between Manchurian ash and larch. In contrast, a study on beech and ash reported significant interspecific differences in $\mathrm{C}$ content (Beyer et al., 2013). Such variation in $C$ across root order is at least partially the result of genetic differences that lead to distinct carbohydrate use and storage capability in a given species (Beyer et al., 2013; Epron et al., 2011).

In conclusion, our study uncovered morphological and functional differentiation of fine roots across Manchurian ash and larch. Indeed, root order was the most important factor in influencing variation across forest type and species. However, root traits in either species did not alter under conditions of intra- or interspecific competition in 30-year mature stands. Our findings therefore suggest that competition may not exert as universal an effect on root characteristics as previously thought; species composition and site conditions may both play a role in determining root response.

Acknowledgements: The Fundamental Research Funds for the Central University (2572016EAJ1) and National Natural Science Foundation of China (NSFC31170583) supported this work. The authors thank three anonymous reviewers and the editor for their helpful comments improving the manuscript.

Competing interests: The author(s) declare no competing interests.

\section{REFERENCES}

Berg, B., and M.C. Laugherty. (2008). Plant Litter. Decomposition, Humus Formation, Carbon Sequestration. Oikos. J. 33(1): 54-65.

Beyer, F., D. Hertel, and C. Leuschner (2013). Fine root morphological and functional traits in Fagus sylvatica and Fraxinus excelsior saplings as dependent on species, root order and competition. Plant and Soil. 373(1-2): 143-156.

Bolte, A. and V. Eva. (2006). Interspecific competition impacts on the morphology and distribution of fine roots in European beech (Fagus sylvatica L.) and Norway spruce (Picea abies (L.) Karst.). European. J. For. Res. 125(1): 15-26.

Casper, B. B. and J. R. Backson (1997). Plant underground competition and carbon sequesition. Ann. Revi. Eco. Sys. 28(1): 545570.

Chen, H. Y., K. Klinka, A.H. Mathey, Wang, X., P. Varga, and C. C. Hourmouzis (2003). Are mixed-species stands more productive than single-species stands: an empirical test of three forest types in British Columbia and Alberta. Canadian. J. For. Rese. 33(7): 1227-1237.

Coomes, D. A. and G.J. Prubb (2000). Impacts of root competition in forests and woodlands: a theoretical framework and review of experiments. J. Ecol. Mon. 70(2); 171-207.

Craine, J. M., J. Froehle, D. G. Tilman, D. A.Wedin, and I. F.S. Chapin (2001). The relationships among root and leaf traits of 76 grassland species and relative abundance along fertility and disturbance gradients. Oikos. J. 93(2): 274-285.

Cui, X. (1997). Spacial patterns of fine root abundance in mixed larch-ash plantation. J. For. Res. 8(4): 206-210.

Curt, T., L.Coll, B. Prévosto, P. Balandier and G. Kunstler (2005). Plasticity in growth, biomass allocation and root morphology in beech seedlings as induced by irradiance and herbaceous competition. Annals For. Sci. 62(1): 51-60.

Eissenstat, D.M. and D. Merhnd (1991). On the relationship between specific root length and the rate of root proliferation: a field study using citrus rootstocks. Advan. Ecol. Res. 83: 64-78.

Eissenstat, D. M., J. M. Kucharski, M. Zadworny, T. S. Adams and R.T. Koide (2015). Linking root traits to nutrient foraging in arbuscular mycorrhizal trees in a temperate forest. New Phyto. 208(1): 114-124.

Eissenstat, D. M., C.E. Wells, R. D. Yanai and , J. L. Whitbeck (2000). Building roots in a changing environment: implications for root longevity. New Phyto. 147(1): 33-42. 
Eissenstat, D. M., and R. D. Yanai (1997). Ecology of Root Life Span. Advan. Ecol. Res. 27: 1-60.

Epron, D., J. Ngao, M. Dannoura, M. R. Bakker, B. Zeller, S. Bazot, and P. Priault (2011). Seasonal variations of belowground carbon transfer assessed by in situ $13 \mathrm{CO} 2$ pulse labelling of trees. Biog. Dis. 8(5): 1153-1168.

Erickson, H. E., C. A. Harrington, and D. D. Marshall (2009). Tree growth at stand and individual scales in two dual-species mixture experiments in southern Washington State, USA. Canadian. J. For. Res. 39(6): 1119-1132.

Falik, O., P. Reides, M. Gersani, and A. Novoplansky (2003). Self/non-self discrimination in roots. J. Ecol. 91(4): 525-531.

Fitter, A. H. (1991). Characteristics and functions of root systems. Plant and soil.67(9): 33-47.

Fornara, D. A., D. Tilman, and S. E. Hobbie (2009). Linkages between plant functional composition, fine root processes and potential soil $\mathrm{N}$ mineralization rates. Plant and soil. 6(9-1): 3347.

Fujii, S. and K. Nasuya (2008). Fine root biomass and morphology of Pinus densiflora under competitive stress by Chamaecyparis obtusa. J. For. Res. 13(3): 185-189.

Gambetta, G. A., J. Fei, T.L. Rost, T. Knipfer, M.A. Matthews, K.A. Shackel (2013). Water uptake along the length of grapevine fine roots: developmental anatomy, tissue-specific aquaporin expression, and pathways of water transport. J. Plan. Phy. 163(3): 1254-1265.

Garnier, E., G. Laurent, A. Bellmann, S. Debain, P. Berthelier, B. Ducout, and M.L. Navas (2001). Consistency of species ranking based on functional leaf traits. New Phytologist. 152(1): 69-83.

George, S. J., B.M. Kumar, P.A. Wahid, and N.V. Kamalam (1996). Root competition for phosphorus between the tree and herbaceous components of silvopastoral systems in Kerala, India. Plant and Soil. 179(2): 189-196.

Gill, R. A. and R.B. Jackson (2000). Global Patterns of Root Turnover for Terrestrial Ecosystems. New Phytologist. 147(1): 13-31.

Gong, Z., X. Zhang, J. Chen, and G. Zhang (2003). Origin and development of soil science in ancient China. Geoderma. 115(1): 3-13.

Gu, J., Y. Xu, X. Dong, H. Wang, and Z. Wang (2014). Root diameter variations explained by anatomy and phylogeny of 50 tropical and temperate tree species. Tree Physiology. 34(4): 415-425.

Guo, D., L. Hei, R. J. Mitchell, W. Han, J.J. Hendricks, T.J. Fahey, and R.L. Hendrick (2008). Fine root heterogeneity by branch order: exploring the discrepancy in root turnover estimates between minirhizotron and carbon isotopic methods. New Phytologist. 177(2): 443-456.

Guo, D., M. Xia, X. Wei, W. Chang, Y. Liu, and Z. Wang (2008). Anatomical traits associated with absorption and mycorrhizal colonization are linked to root branch order in twenty-three Chinese temperate tree species. New Phytologist. 180(3): 673-683.

Hauggaard, N.H., P. Ambus, and E.S. Jensen (2001). Temporal and spatial distribution of roots and competition for nitrogen in pea-barley intercrops a field study employing ${ }^{32} \mathrm{P}$ technique. Plant and Soil. 236(1): 63-74.

Hees, A. V. (1997). Growth and morphology of pedunculate oak (Quercus robur L) and beech (Fagus sylvatica L) seedlings in relation to shading and drought. Ann. Des. Sci. For. 54(1): 9-18.

Hertel, D., D. Hölscher, L. Köhler, and C. Leuschner (2006). Changes in Fine Root System Size and Structure During Secondary Succession in a Costa Rican Montane Oak Forest. Spr. Ber. Hei. 20(3): 73-82.

Hodge, A. and A. H. Fitter (2010). Substantial nitrogen acquisition by arbuscular mycorrhizal fungi from organic material has implications for $\mathrm{N}$ cycling. Proc. Nat. Aca. Sci. 107(31): 1375413759 .

Hubersannwald, E., M.M. Caldwell, and D.A. Pyke (1997). Perception of neighbouring plants by rhizomes and roots: morphological. Canadian J. Bot. 75(12): 2146-2157.

Jose, S., R. Williams, and D. Zamora (2006). Belowground ecological interactions in mixedspecies forest plantations. For. Ecol. Manag. 233(2-3): 231-239.

Kong, D., M.C. Zhang, Q. Li, L. Chen, X. Zeng, and D. Guo (2014). Leading dimensions in absorptive root trait variation across 96 subtropical forest species. New Phytologist. 203(3): 863-872.

Kong, D. L., J.J. Wang, P. Kardol, H.F. Wu, H. Zeng, X.B. Deng, and Y. Deng (2016). Economic strategies of plant absorptive roots vary with root diameter. J. Bio. Sci. 13(2): 20-34.

Lei, P., M. Schererlorenzen, and J. Bauhus (2012). Belowground facilitation and competition in young tree species mixtures. For. Ecol. Manag. 265(1): 191-200.

Lei, X., W. Wang, and C. Peng (2009). Relationships between stand growth and structural diversity in spruce-dominated forests in New Brunswick, Canada. Canadian. J. For. Res. 39(10): 18351847.

Leuschner, C., D. Hertel, I. Schmid, O. Koch, A. Muhs, and D. Hölscher, (2004). Stand fine root biomass and fine root morphology in old-growth 
beech forests as a function of precipitation and soil fertility. Plant and Soil. 258(1): 43-56.

Li, J., Salahuddin, J. Zhang, L. You, C. He, and L. Yang (2016). Larch (larix gmelinii) bulk soil phenolic acids promote manchurian walnut (juglans manshurica) growth and soilmicroorganism biomass. Pakistan. J. Bot. 48(6): 2549-2556.

Luke, M.M., T.S. Adams, E.A. Smith, and D.M. Eissenstat. (2012). Predicting fine root lifespan from plant functional traits in temperate trees. New Phytologist. 195(4): 823-831.

Lynch, J. (1995). Root Architecture and Plant Productivity. Plant Physiology. 109(1): 7-13.

Majdi, H., Pregitzer, M. Kurt, A.S. Moren, and Goran, I (2005). Fine root turnover in forest ecosystems : Measuring fine root turnover in forest ecosystems. Plant and Soil. 276(1-2): vii-viii.

Mccormack, M. L., I. A. Dickie, D. M. Eissenstat, T.J. Fahey, C.W. Fernandez, and D. Guo (2015). Redefining fine roots improves understanding of below-ground contributions to terrestrial biosphere processes. New Phytologist. 207(3): 505-518.

Norby, R. J., J. Ledford, C.D. Reilly, N.E. Miller, and E.G. Neill (2004). Fine-root production dominates response of a deciduous forest to atmospheric CO2 enrichment. Proc. Nat. Aca. Sci. Uni. Stat. Amer. 101(26): 9689.

Orwin, K. H., S. M. Buckland, D. Johnson, B. L. Turner, S. Smart, S. Oakley, and R.D. Bardgett (2010). Linkages of plant traits to soil properties and the functioning of temperate grassland. J. Ecol. 98(5): 1074-1083.

Ostonen, I., K. Lohmus, S. Alama, J. Truu, E. Kaar, A. Vares, and V. Kurvits (2006). Morphological adaptations of fine roots in Scots pine (Pinus sylvestris L.), silver birch (Betula pendula Roth.) and black alder (Alnus glutinosa (L.) Gaertn.) stands in recultivated areas of oil shale mining and semicoke hills. Oil Shale. 23(2): 187-202.

Poorter, H., A.V.D. Werf, O. K. Atkin, and H. Lambers (1991). Respiratory energy requirements of roots vary with the potential growth rate of a plant species. Physiologia Plantarum. 83(3): 469-475.

Pregitzer, K. S. (2002). Fine roots of trees - a new perspective. New Phytologist. 154(2): 267-270.

Pregitzer, K. S., J.L. Deforest, A. J. Burton, M.F. Allen, R.W. Ruess, and R.L. Hendrick (2002). Fine root architecture of nine north American trees. J. Ecol. Mon. 72(2): 293-309.

Razaq, M., H.l. Shen, H. Sher, and P. Zhang (2017). Influence of biochar and nitrogen on fine root morphology, physiology, and chemistry of Acer mono. J. Sci. Rep. 7: 53-67.
Reich, P. B. (2014). The world-wide 'fast-slow' plant economics spectrum: a traits manifesto. J. Eco. 102(2): 275-301.

Reich, P. B., M.B. Walters, M.G. Tjoelker, D. Vanderklein, and C. Buschena (1998). Photosynthesis and respiration rates depend on leaf and root morphology and nitrogen concentration in nine boreal tree species differing in relative growth rate. J. Fun. Eco. 12(3): 395-405.

Rewald, B. and C. Leuschner (2009). Belowground competition in a broad leaved temperate mixed forest: pattern analysis and experiments in a four-species stand. Euro. J. For. Res. 128(4): 387-398.

Rewald, B., C. Meinen, and S. Rachmilevitch (2010). Root taxa identification in plant mixtures Current techniques and future challenges. Nat. Bur. Econ. Res. Inc. 65-77

Rewald, B., C. Meinen, M. Trockenbrodt, J.E. Ephrath, and S. Rachmilevitch (2012). Root taxa identification in plant mixtures current techniques and future challenges. Plant and Soil, 359(1-2): 165-182.

Salahuddin, R. Boris, M. Razaq, Y.L. xue, and J. Li (2018). Root order-based traits of Manchurian walnut \& larch and their plasticity under interspecific competition. J. Sci. Rep. 8(1): 9815.

Schenk, H. J. (2006). Root competition: beyond resource depletion. J. Ecol. 94(4): 725-739.

Schenk, H. J., Callaway, R. M., \& Mahall, B. E. (1999). Spatial Root Segregation are plants territorial. Adv. Ecol. Res. 28(08): 145-180.

Tjoelker, M. G., J.M. Craine, D. Wedin, P. B. Reich, and D. Tilman (2005). Linking leaf and root trait syndromes among 39 grassland and savannah species. New Phytologist. 167(2): 493-508.

Wahl, S., and P. Ryser (2000). Root tissue structure is linked to ecological strategies of grasses. New Phytol. 148(3): 459-471.

Wang, W., Y. Wang, G. Hoch, Z. Wang, and J. Gu (2018). Linkage of root morphology to anatomy with increasing nitrogen availability in six temperate tree species. Plant and Soil. 45(3): 112.

Wells, C. E., and D.M. Eissenstat (2002). Beyond the Roots of Young Seedlings: The Influence of Age and Order on Fine Root Physiology. J. Plan. Gro. Regu. 21(4): 324-334.

Wilson, J. B. (1988). Shoot Competition and Root Competition. J. App. Ecol. 25(1): 279-296.

Withington, J. M., P.B. Reich, J. Oleksyn, and D.M. Eissenstat (2006). Comparisons of structure and life span in roots and leaves among temperate trees. J. Ecol. Mono. 76(3): 381-397. 
Xia, M., D. Guo, and K.S. Pregitzer (2010). Ephemeral root modules in Fraxinus mandshurica. New Phytologist. 188(4): 1065-1074.

Yang, L. (2006). Bioassay of Allelopathical Activity of Larch (Larix gmelini) Aqueous Extracts against Juglans mandshurica. J. Nor. For. Uni. 34(1): 15-17.

Yang, L., W. Peng, and C. Kong (2010). Effect of larch ( Larix gmelini Rupr.) root exudates on Manchurian walnut ( Juglans mandshurica Maxim.) growth and soil juglone in a mixed- species plantation. Plant and Soil. 329(1-2): 249258.

Zhang, J., Salahuddin, H. Yuan, H. Yang, L. Wang, and L. You (2016). Effects of larch (Larix gmelinii) phenolic acids on Manchurian ash (Fraxinus mandshurica) soil microbial community structure. Allelopathy. J. 37(1): 123-135.

Zhang, Y., Y. Shen, S. Bai, and Z. Wang (2001). Effects of the mixed on root growth and distribution of fraxinus mandshurica and larix gmelinii. J. Sci. Sil. Sin. 37(5): 16-23. 